29. Среднее Поволжье в цифрах. Общедоступный статистический справочник / сост. Г.Г. Котов. Самара: Гос. изд-во. Ср.-Волж. обл. отделение, 1929. $229 \mathrm{c}$.

30. Статистика Оренбургского края. Оренбург: Оренбургский областной комитет государственной статистики, 2002. 179 с.

31. Чкаловская область в третьей пятилетке: сб. статей. Чкалов: Областное издательство, 1939. 73 с.
32. Попов М.В. Культура и быт крестьян Урала в 1920-1941 годах. Екатеринбург, 1997. 201 с.

33. Народное образование, наука и культура в СССР: стат. сб. М.: Статистика, 1971. 402 с.

34. Народное образование, наука и культура в Оренбургской области: стат. сб. ЦСУ РСФСР. Статистическое управление Оренбургской области, 1975. $152 \mathrm{c}$.

\title{
THE LEVEL OF LITERACY OF THE ADULT POPULATION OF THE ORENBURG REGION ACCORDING TO THE MATERIALS OF THE FIRST SOVIET CENSUS
}

(C) 2017

Petrich Larisa Vladimirovna, candidate of historical sciences, associate of History of Russia Department

Lyubichankovskiy Sergey Valentinovich, doctor of historical sciences, professor, head of History of Russia Department

Orenburg State Pedagogical University (Orenburg, Russian Federation)

Abstract. This paper analyzes the evolution of literacy in different categories of the Orenburg region adult population according to the censuses in 1920,1926 and 1939 as well as the influence of the educational policy of the Soviet state. The analysis of the census gives an opportunity to give literacy demographic characteristics: gender, age, nationality, social status, occupation, etc. The author notes that the proclamation of compulsory education principle for illiterate adults and the organization of universal education for school-age children gave an opportunity for education to all categories of the Soviet Russian population. Literacy level started to rise; it was reflected in the census. The censuses of 1926, 1939 showed that literacy level of certain age groups in different generations rose after the October revolution. The paper has a certain pattern: the older the generation age was, the higher the level of literacy was. Generalized materials of the first Soviet censuses allow us to conclude that the effect of positive and negative factors in the education of children and illiterate adults was different in urban and rural areas. As a rule, more women and men had a chance for education in urban areas. The results of the study allow us to conclude on the impact of the Soviet government activities to adult education.

Keywords: census of population; national population census in 1920; census of all-Union population in 1926; census of 1939; elimination of illiteracy; literacy level; education of population; universal education; demographic processes; Orenburg province; Orenburg region.

\section{САМАРСКОЕ КРАЕВЕДЧЕСКОЕ ДВИЖЕНИЕ 1920-1930-Х ГОДОВ И ЕГО ВКЛАД В ИЗУЧЕНИЕ И ОХРАНУ ПРИРОДЫ СРЕДНЕГО ПОВОЛЖЬЯ}

(C) 2017

Макеева Екатерина Дмитриевна, кандидат исторических наук, доцент кафедры физики, математики и методики обучения

Самарский государственный соииально-педагогический университет (г. Самара, Российская Федераиия)

Аннотация. Изучение российской экологической истории является одной из актуальных задач современной науки, так как позволяет перенять полезный исторический опыт в условиях обострения взаимоотношений общества и природы. Охрана природы в России всегда была тесно связана с исследованием малой родины, своего родного края, являясь одним из важнейших направлений как научного, так и любительского краеведения. В данной статье рассматривается вклад в изучение и охрану природы Среднего Поволжья самарского краеведческого движения в 1920-1930-е гг., в том числе одного из самых значимых научных обществ того времени - Самарского общества археологии, истории, этнографии и естествознания и его преемника. В его составе в «золотой век краеведения» (1920-е гг.) работали самые известные самарские ученые, оставившие уникальное научное наследие. Их труды заложили основы современного естественнонаучного краеведения, заповедного дела и общественного движения за охрану природы в Самарской области. Источниками для подготовки статьи послужили, в основном, материалы Центрального государственного архива Самарской области. Значительное количество архивных документов впервые вводится в научный оборот, что составляет научную новизну исследования.

Ключевые слова: краеведческое движение; краеведение; охрана природы; природоохранная деятельность; Самарское общество археологии, истории, этнографии и естествознания; Самарское научно-краеведческое общество.

На протяжении столетий краеведение является своеобразной формой общественного социокультурного движения. Деятельность краеведов-любителей всегда была направлена на исследование прошлого и

настоящего родного края, его природы, а также популяризацию полученных сведений среди местного населения. Начиная со второй половины XVIII в., наряду с любительским краеведением в России раз- 
вивается научное краеведение. Его центрами в XIX в. становятся провинциальные университеты (в Казани, Харькове, Киеве, Одессе), местные отделения научных обществ, а также первые краеведческие музеи. «Золотым десятилетием» отечественного краеведения, то есть периодом его небывалого распространения, считаются 1920-е гг., когда число краеведческих организаций в стране увеличилось в десять раз $[1$, с. 9-10]. Это десятилетие в истории краеведения занимает особое место, так как именно оно стало временем формирования по-настоящему массового краеведческого движения, существовавшего в форме разнообразных добровольных и государственных объединений и союзов граждан, функции которых заключались во всестороннем изучении отдельных регионов и местностей страны.

Особенно интересна и разнообразна история поволжского, в том числе, самарского краеведения, которое по своей общей направленности, выработке форм и методов работы, энтузиазму всегда стояло в ряду наиболее активных. Благодаря краеведческому движению на территории Самарской губернии в 1920-е гг. получили развитие различные направления научных исследований в сфере археологии, этнографии, геологии, зоологии, ботаники. Деятельность краеведов способствовала не только обнаружению сведений о заселении местного края, его древней истории, геологическом строении, особенностях животного и растительного мира и т.д., но и выявлению и подробному изучению природных территорий, нуждающихся в особо бережном отношении и охране в силу своей уникальности, а также популяризации природоохранных идей среди населения.

Целью нашего исследования явилось изучение роли Самарского краеведческого движения в исследовании и охраны природы Среднего Поволжья.

Научное изучение природы Самарского края началось еще в XVIII в., когда на его территории побывали экспедиции путешественников и естествоиспытателей: П.С. Палласа, И.И. Лепёхина, И.П. Фалька. В их трудах содержатся подробные сведения о флоре и фауне исследованной территории. В начале XX в. в Среднем Поволжье в разное время работали видные ученые России: ботаники В.Н. Сукачев, Г.Н. Высоцкий, В.И. Талиев, почвоведы А.И. Бессонов, С.С. Неуструев, Л.И. Прасолов и др. Именно в научной среде зародились идеи о необходимости целенаправленной работы по сохранению природы региона. Профессор Санкт-Петербургского лесного института В.Н. Сукачев еще в 1914 г. призывал правительство и общественность страны создать в Жигулевских горах заповедник. Однако плодотворное развитие и воплощение в жизнь природоохранных идей на территории Среднего Поволжья связано, прежде всего, с деятельностью научно-краеведческих обществ Пензенской и Самарской губерний, в состав которых в те годы входила, в основном, местная интеллигенция: краеведами были ученые - историки, биологи и географы, работники музеев, учащиеся и преподаватели местных школ и высших учебных заведений, сотрудники советских и хозяйственных органов.

В 1918 г. в Самаре был основан государственный университет, а в 1919 г. при нем открылось Самарское общество археологии, истории и этнографии (СОАИЭ), на базе существовавшего в городе с
1916 г. археологического общества [2, л. 1]. Первым председателем СОАИЭ был избран А.С. Башкиров, занимавший этот пост в 1919-1922 гг. После него обществом руководили П.П. Фридолин (1922-1923 гг.), В.П. Арапов (1923-1928 гг.) и П.А. Преображенский (1928-1930 гг.). Деятельность СОАИЭ первое время протекала в крайне неблагоприятных условиях, так как не было собственного помещения, и наблюдался «крайний недостаток в материальных средствах. В течение почти 10 месяцев (с ноября 1919 г. по август 1920 г.) Общество работало совсем без кредитов и легализации» [2, л. 6]. Пришлось изыскивать средства в виде пожертвований, которые были внесены Самарским Губисполкомом, Средне-Волжским Союзом Потребителей и Правлением Кооператив Банка. Эти деньги, хоть и не покрыли всех нужд общества, по крайней мере, позволили ему просуществовать первое время. После трех месяцев ходатайств в Москве, А.С. Башкиров добился легализации Общества и открытия ему кредита в один миллион рублей $[2$, л. 4 об.]. Усилия для этого были потрачены немалые. Безусловно, время было очень тяжёлое, и у руководства молодой Советской республики были дела более важные, чем развитие краеведческого движения. Однако в своем городе, несмотря на трудные времена, СОАИЭ встречало поддержку со стороны местных правительственных и общественных учреждений, а также отдельных лиц, как в Самаре, так и в различных уездах. А члены общества, по их собственным словам, получали «полное нравственное удовлетворение и уверенность в выполнении всех намеченных планов: детального обследования Самарского края» [2, л. 6].

К концу 1920 года в СОАИЭ состояло уже 54 человека: действительных членов-учредителей - 14 человек, действительных членов - 19 человек и членовсотрудников - 21 человек [2, л. 4]. Несмотря на трудности, Общество открывало свои отделения в уездных центрах, например, в 1919 г. в его состав были приняты Пугачевское археологическое общество и Ставропольское общество по изучению местного края [3, л. 9].

В мае 1922 г. в составе общества была организована секция естествознания, внесены изменения в его Устав, и с этого момента СОАИЭ стало называться «Самарское общество археологии, истории, этнографии и естествознания» (СОАИЭиЕ) при Самарском государственном университете [4, л. 1]. Его целью являлось «изучение духовной и материальной культуры прошлого и настоящего, природы и народов, населяющих Самарский край и прилегающие к нему области, содействие в распространении знаний» [5, л. 14]. А среди его основных задач значились: организация наблюдений за природой, сбор коллекций для музея, проведение научных конференций, экспедиций, организация лабораторий и опытных станций, издание научных трудов и создание научной библиотеки [5, л. 14 об. - 15]. С этого момента изучение и охрана природы края становится одним из основных направлений деятельности общества.

Успешная работа СОАИЭиЕ уже в 1922 г. была отмечена Центральным бюро краеведения, а также Президиумом Самарского Губисполкома [4, л. 6], однако, в условиях войны и экономического кризиса 
работа по-прежнему протекала в «исключительно тяжёлых условиях: не было средств не только на научные исследования, но и на отопление занимаемого помещения» $[4$, л. 6]. Со временем экономическая ситуация в Поволжье улучшилась, и, начиная с 1924 г., СОАИЭиЕ стало понемногу финансироваться Губисполкомом, с 1928 г. обществу ежегодно выделялось 5000 руб. из областного бюджета и 1500 руб. из Облплана [6, л. 4 об.]. Регулярные денежные поступления позволили краеведам активизировать издательскую, научно-исследовательскую и просветительскую деятельность. Были опубликованы сборник «Краеведение» (1924 г.) и справочник «Вся Самара за 1925 год» (1925 г.) [7, л. 1 об.], составлен библиографический указатель литературы по геологии края, обследованы в геологическом отношении большая часть Самарской Луки, северной Приволжской полосы и дюн реки Самары в пределах Бузулукского уезда, выявлено наличие торфяных болот и залежей торфа в пределах Самарского, Мелекесского, Бузулукского и Бугурусланского уездов, обследованы соляные источники близ села Усолья и изучена возможность их эксплуатации, систематизирован гербарный материал и составлен определитель растений Самарского края $[8$, с. 3]. Членами общества в 1924 г. был прочитан цикл лекций общедоступного характера по вопросам краеведения и естествознания под общим названием «Богатства Самарского края» в Самарском губернском музее, а также опубликована серия заметок и статей в местной газете «Коммуна» об истории края, его освоении людьми, различных исторических событиях, местных природных богатствах и достопримечательностях Серной горе, Царевом кургане, Самарской Луке и т.д. [9, л. 8 об.].

Весной 1927 г. членами секции естествознания СОАИЭиЕ в школах Самары была развернута сеть фенологических наблюдений (наблюдений за сезонными явлениями природы, сроками их наступления и причинами, определяющими эти сроки). Инициаторами и организаторами этого проекта были В.П. Арапов, Б.Н. Медведев и А.Ф. Терехов [10, л. 14]. В.П. Арапов справедливо считал, что «организация фенонаблюдений в школах - это один из лучших приемов развития у учащихся сознательного отношения к явлениям окружающей природы» [11, л. 23]. В ходе этой работы школьниками собирался достаточно ценный материал, который обобщался в специальных «дневниках природы», и позволял ученым-краеведам делать важные научные выводы.

Исследуя природу Среднего Поволжья, самарские краеведы пристальное внимание обращали на Бузулукский бор, где еще в начале XX в. по инициативе русского ученого Г.Ф. Морозова было учреждено первое в стране опытное лесничество и начались поиски эффективных научных приемов лесоразведения. В 1926-27 гг. краеведами были организованы научные экспедиции в Бузулукский бор, итогом которых стал вывод о том, что главной угрозой для него является деятельность человека, и поэтому антропогенное влияние на этот участок природы необходимо ограничить [12, л. 35]. Проблема сохранения и восстановления Бузулукского бора неоднократно обсуждалась на заседаниях СОАИЭиЕ [12, л. 34], и, именно благодаря многолетней планомерной работе ученой общественности 1933 г. был создан заповедник «Бузулукский бор», просуществовавший до 1948 г. [13, л. 45]. В дальнейшем на его территории находился государственный заказник.

Также члены СОАИЭиЕ поддержали идею известного ученого, директора Пензенского государственного заповедника И.И. Спрыгина о выделении заповедной территории в Жигулевских горах. Была организована комплексная экспедиция по изучению природы Жигулей, и в 1927 г. на территории Самарской Луки открылся Жигулевский участок Пензенского государственного заповедника площадью в 2300 гектаров, куда вошли села Отважное, Моркваши, Бахилова поляна, овраги Малиновый и Холодный $[14$, л. 1]. В связи с увеличением площади, Пензенский государственный заповедник был переименован в Средневолжский [13, л. 72; 15, л. 49]. Кроме того, несколько объектов и территорий Среднего Поволжья получили статус памятников природы: Молодецкий курган, Лысая гора, Царев курган, устье реки Усы и др. [13, л. 45]. Порубку леса и разработку камня в намеченных участках считалось необходимым запретить. В 1935 г. Средневолжский заповедник стал Куйбышевским, и под этим названием он просуществовал вплоть до своей ликвидации в 1951 г. (в дальнейшем, в 1959 г. на части его территории был основан Жигулевский заповедник).

1927 год вообще стал весьма продуктивным в плане развития природоохранного дела в России. По всей стране при губернских отделах народного образования (ГубОНО) были образованы междуведомственные комиссии по охране природы. Появилась такая комиссия и в Самаре [16, л. 250], причем работала при Самарском обществе археологии, истории, этнографии и естествознания и под руководством его председателя - В.П. Арапова. Наркомпрос РСФСР уполномочил именно его, главу местного научнокраеведческого общества, быть представителем Отдела охраны природы Главнауки в Самарской губернии, а ГубОНО возложило на него всю работу по организации комиссии. Необходимо отметить, что Владимир Петрович Арапов сыграл огромную роль в становлении дела охраны природы в Самаре, фактически он руководил всей природоохранной работой в СОАИЭиЕ - единственной организации, которая в то время планомерно и квалифицированно изучала природу Самарской губернии. И даже покинув пост председателя СОАИЭиЕ в 1928 г., В.П. Арапов продолжил свою деятельность, оставаясь руководителем секции естествознания общества.

Самарская междуведомственная комиссия по охране природы состояла из 28 человек, в нее входили представители как общественных организаций, так и местных органов власти и учреждений: Губисполкома, Губоно, Губземуправления, Горздрава, Губкома ВЛКСМ, Горсовета, местных научно-исследовательских учреждений и обществ (Безенчукской сельскохозяйственной опытной станции, областного музея, Научного общества врачей, СОАИЭиЕ, Приволжского геодезического комитета, Волжского горного округа, сельскохозяйственного института), а также сотрудников Главлесоохраны [17, л. 130-131]. На первом же заседании комиссии состоялось обсуждение вопроса об учреждении Жигулевского заповедника. В своем докладе В.П. Арапов с сожалением 
Макеева Е.Д.

констатировал, что «ценным местом для заповедника мог бы служить Яблоневый овраг под Морквашами, хорошо исследованный и очень интересный в геологическом отношении, но, вследствие порубки леса, это место уже обесценено в отношении естественных исследований» $[14$, л. 1]. Также члены комиссии обсуждали вопросы, связанные с созданием степных заповедников Бузулукская степь (Козявка) и Пугачевская степь [14, л. 1 об.]. Со стороны Главнауки РСФСР и местных органов власти наблюдалось благоприятное отношение к созданию новых охраняемых природных территорий, но существенным препятствием были финансовые трудности [14, л. 2]. Денег на охрану природы у страны по-прежнему не было, эта сфера деятельности оставалась второстепенной, однако разногласий между властью и общественностью в данной сфере еще не возникало. Ситуация резко изменилась в конце 1920-х - начале 1930-х гг., когда Советский Союз взял курс на индустриализацию, и было развернуто масштабное социалистическое строительство. Интересы природы были принесены в жертву потребностям развития промышленности и научное сообщество и общественные силы, пропагандирующие природоохранные идеи, стали восприниматься властью как помеха в реализации грандиозных планов «покорения природы». Призывам ученых - краеведов и естествоиспытателей к сбережению природных богатств зачастую придавалась политическая окраска, поэтому вместе с началом широкомасштабной индустриализации в СССР начинаются гонения краеведческого, а вместе с ним и природоохранного движения.

После массовых проверок и перерегистрации, состоявшихся по всей стране в 1929-1930 гг., многие краеведческие, научные и природоохранные общества в регионах, созданные еще до революции или вскоре после нее, были закрыты или реорганизованы, прикреплены к соответствующему вузу, научному или другому государственному учреждению. Те же, что остались, были вынуждены существенно изменить характер своей деятельности. В Самаре в 1927 г. из-за финансовых трудностей был университет, и, в связи с этим, в марте 1929 г. было реорганизовано и состоящее при нем Общество археологии, истории, этнографии и естествознания. Вместо него было образовано Самарское научно-краеведческое общество (СНКО), деятельность которого, в соответствии с новыми установками партии и правительства, предполагалось, во-первых, направить в русло массовой работы, а, во-вторых, увязать с выполнением пятилетнего плана народного хозяйства края [20, л. 47-47 об.]. Соответственно, и целью общества стало «изучение производительных сил округа и краеведческое изучение всего Средневолжского края с привлечением к этой работе желающих: не только отдельных лиц, но и целых учреждений, заинтересованных в знании края» [21, л. 12]. Необходимо отметить, что на рубеже 1920-1930-х гг. произошла переориентация всего советского краеведческого движения с изучения местного края в научных и просветительских целях на изучение местного края в целях поиска ресурсов, полезных для народного хозяйства страны. Эта переориентация существенно изменила как направления деятельности краеведческого движения, так и формы его организации.
Лучшую характеристику целей и задач своей работы на данном этапе дали сами краеведы: это «борьба с природой, отвоевывание у нее тех нужных для человечества богатств, которые она запрятала в недра земли. Краеведам нужно заниматься исследовательскими работами во многих областях нашего народного хозяйства, им нужно помогать развитию нашего социалистического строительства, обеспечивать его сырьем» [18, л. 109 об.]. Это высказывание принадлежит ученому секретарю Бугурусланского краеведческого общества Аниховскому. А вот как на первом же собрании сформулировали задачи своей деятельности члены Кружка краеведов-натуралистов, созданного в 1931 г. при Боровой опытной лесной станции: борьба с браконьерством, распространение природоохранных идей среди широких масс населения, а также борьба «с сюсюкающим либерализмом, ставящим охрану природы исключительно ради эстетических целей, мешающих строительству социализма. ... Работа нашей организации должна иметь целью выявление природных богатств Бузулукского бора, находящихся до сего времени в стадии омертвления, а также охрану ценных и редких объектов от хищнического истребления браконьерами для создания возможностей рационального использования их государством» [19, л. 5-6].

В Поволжье в конце 1920-х гг. были изменены административные границы: в мае 1928 г. Самарская губерния вошла в состав Средне-Волжской области (с октября 1929 г. - Средне-Волжский край). Было образовано Средне-Волжское краевое бюро краеведения, в составе которого в 1931 г. появилась секция изучения и охраны природы [22, л. 59]. Краевое бюро краеведения, в отличие от СОАИЭиЕ или СНКО, уже не являлось добровольной общественной организацией, так как оно было создано по формальному признаку официального представительства от местных учреждений и организаций. Территория СреднеВолжского края делилась на округа, и в каждом из них в 1930-1932 гг. были созданы окружные краеведческие бюро «взамен или на базе обществ краеведения» $[18$, л. 6]. Особое внимание стало уделяться привлечению населения к краеведческой работе с целью повышения ее массовости. Об этом говорилось практически в каждом плане и отчете [19, л. 14 , 41-44; 22, л. 26-31, 33-34], на каждом заседании, совещании или съезде краеведов подчеркивалось, что успехи всестороннего изучения природы, хозяйства и культуры края в целях социалистического строительства возможны только при условии «широкого вовлечения в краеведческое движение и работу Общества трудящихся масс города и деревни» [11, л. 39].

Во многих районах до этого краеведческая работа совершенно не велась $[18$, л. 14, 20], и поэтому организации здесь создавались практически «на пустом месте», по указанию «сверху». Не было для этого ни соответствующих кадров, ни средств, ни специальной литературы, о чем свидетельствуют многочисленные письма с жалобами и просьбами о помощи, поступающие в Краевое бюро краеведения, руководство которого базировалось в Самаре, из городов и районов всего Средне-Волжского края [18, л. 4, 14, 15, 20, 34 об., 39, 68, 152, 153 и др.]. В них также отмечалось, что на местах люди очень равнодушно от- 
носятся к краеведческой работе, и даже в райцентрах никто не принимает в ней горячего участия [18, л. 20]. Так, председатель Мелекесского райбюро краеведения Леонтьев писал: «Главным препятствием к развертыванию краеведческой работы является отсутствие средств на эту работу и косность общественных организаций» [18, л. 83]. И это неудивительно, ведь если в губернских центрах костяк краеведческого движения составляла научная интеллигенция: местные ученые, преподаватели вузов и сотрудники музеев, то в глубинке деятельность общественных организаций чаще всего строилась на энтузиазме местных учителей, а их социальный состав был совсем иной. Например, в Бугурусланском районно-городском обществе краеведения в 1930 г. состояли: крестьяне $-51 \%$, служащие $-37,5 \%$, рабочие - 11,5\%. Естественно, крестьянство, составлявшее более половины членов местных краеведческих ячеек, и вступавшее в них, чаще всего, по принуждению колхозного начальства, в силу своей необразованности просто не могло осуществлять работу по исследованию местного края на том же уровне, что и городская интеллигенция.

В итоге появилось множество новых краеведческих ячеек и бюро в отдельных учреждениях, городах, райцентрах и селах, деятельность которых носила, зачастую, формальный характер. В 1932 г. в городах и районах Средне-Волжского края существовало 35 краеведческих организаций, а также 316 краеведческих ячеек и кружков юннатов (при школах, техникумах, домах работников просвещения, колхозах, заводах, фабриках, сельсоветах, редакциях местных газет) с общим количеством членов 5054 человек [18, л. 7]. В отдельных случаях краеведы сами вынуждены были признать, что их организации либо существуют только на бумаге, либо ведут работу в крайне малом объеме, не выполняя поставленные задачи.

В связи с развертыванием широкой программы по превращению Среднего Поволжья в передовой индустриально-аграрный край, значительно активизировалась научно-исследовательская работа по изучению природы данных территорий. Краеведческие организации получали задания по поиску и изучению местных природных богатств: энергетических ресурсов, полезных ископаемых, сырья для изготовления строительных материалов, сельскохозяйственных ресурсов; экономическому обоснованию гидростроительства и т.д. Однако идеи охраны природы не были забыты Самарским научно-краеведческим обществом, в его составе появилась секция по изучению естественно-исторических условий, председателем которой стал В.П. Арапов. На первом же ее заседании был заслушен доклад И.И. Спрыгина «Методы исследования охраны природы края» [23, л. 22].

Начиная с 1929 г., деятельность СНКО постепенно приходила в упадок, и в 1931 г. оно было ликвидировано. Это событие было следствием репрессий в отношении старейших краеведов и деятелей охраны природы, ученых дореволюционной школы, начавшихся в Москве, а затем перекинувшихся в регионы. В сентябре 1930 г. было арестовано около 60 членов СНКО, в том числе и В.П. Арапов. Все они проходили по уголовному делу так называемой Трудовой Крестьянской партии (ТКП). После этого общество было закрыто, а его богатейшие коллекции и библиотека переданы Самарскому краевому музею и педагогическому институту. Незадолго до ликвидации, на собрании общества прозвучало, что, несмотря на открытие нескольких отделений СНКО в городах, селах и райцентрах края, вовлечь в краеведческую работу народные массы так и не удалось из-за отсутствия средств и сил. Особенно сложно поддерживалась связь с краеведческими ячейками на местах, где от СНКО требовали предоставления специальной литературы и оборудования. Общество удовлетворить эти требования было не в состоянии. Недостаточное вовлечение населения в краеведческую работу, означавшее невыполнение директив партии и вышестоящих органов, стало одной из причин закрытия Самарского научно-краеведческого общества.

В.П. Арапов в 1931 г. был приговорен к 10 годам заключения, однако, благодаря многочисленным ходатайствам научной общественности, дело против него вскоре было пересмотрено, и в 1934 г. он был условно освобожден. Ему удалось устроиться на работу в Ботанический сад, где он вновь попытался развернуть работу по изучению природы Самарского края. Однако в октябре 1937 г. В.П. Арапов снова был арестован. Его и других членов СНКО обвинили в том, что их организация «объединяла в своем составе реакционно-монархическую верхушку старой научной интеллигенции, бывших церковников и прочий контрреволюционный элемент, который был использован в активной борьбе против Советской власти и ВКП(б) контрреволюционной организацией «Трудовая крестьянская партия», ликвидированной в 1930 г. органами ОГПУ [24, с. 89-98]. 15 февраля 1938 г. Арапов В.П. и некоторые другие самарские краеведы были расстреляны. А оставшиеся в живых члены СНКО были отправлены по этапу в лагеря, где многие из них скончались. К сожалению, такова была судьба многих советских ученых, активно пропагандирующих в 1930-е гг. идеи охраны природы.

После закрытия СНКО краеведческая работа в Самаре продолжалась силами местных ячеек и бюро краеведения, еще несколько лет активно шло изучение природы и производительных сил Среднего Поволжья. Средневолжское краевое бюро краеведения ежегодно организовывало геологоразведочные экспедиции, в ходе которых были найдены залежи горючих полезных ископаемых: торфа, сланцев; сырья для производства строительных материалов: известняка, мела, глин, щебня; различных руд, фосфоритов и др. Особенно массовый геологический поход «за сырьем для станков второй пятилетки» состоялся в 1933 г. Руководил этим походом Крайисполком, а участвовали в его проведении местные органы власти каждого района: Райисполкомы, Райпланы, РайОНО, РК ВЛКСМ, райдоротделы и другие организации. К геопоходу были привлечены учащиеся школ, студенты техникумов и вузов, рабочие. Также исследовались местные водоемы, которые, разливаясь, подтапливали территории, изучалась флора на предмет поиска мест произрастания лекарственных растений. В связи с разработкой проектов масштабного гидростроительства на Волге и Каме краеведами были начаты работы по изучению природных условий в Татарской республике и на Самарской Луке [22, л. 22 
об., 23, 35, 36, 36 об., 42-45]. Продолжались и фенологические наблюдения, начатые под руководством В.П. Арапова. В 1934 г. на территории края действовало 89 фено-точек, а в 1935 г. был основан центр фенологических наблюдений.

Средне-Волжское бюро краеведения просуществовало до 1935 г., после чего было реорганизовано, и вместо него появилось Общество изучения Куйбышевского края, которое продолжило многие темы исследований, выдвинутые краеведами ранее [25, c. 37-40]. Оно проработало всего три года (с 1935 по 1937 гг.), и сведений о его деятельности сохранилось немного. Однако известно, что в 1936 г. Обществом изучения Куйбышевского края, совместно с отделом народного образования Крайисполкома, была предпринята попытка открыть краевое отделение Всероссийского общества охраны природы (ВООП), и с этой целью в Президиум Крайисполкома была направлена докладная записка, в которой отмечалось, что в связи с бурным ростом социалистического строительства, область работы по охране наиболее ценных участков природы, имеющих научное и практическое значение в народном хозяйстве нашей страны, требует к себе особого внимания [26, л. 55]. «До настоящего времени, - отмечалось в записке, - в Куйбышевском крае дело охраны природы ограничивалось исключительно небольшой территорией заповедников, между тем как на огромном пространстве нашего края имеется значительное количество объектов, подлежащих охране» [26, л. 55].

Предложение было рассмотрено Куйбышевским Крайисполкомом, и в феврале 1936 г. появился проект Постановления «Об организации Краевого отделения Общества Охраны Природы», в котором говорилось: «Считая, что до сего времени в Куйбышевском крае дело охраны природы велось только в узких пределах заповедных территорий и, принимая во внимание необходимость создания в городе Куйбышеве специальной организации по охране природы с привлечением к этой важнейшей работе широких слоев советской общественности, Краевой Исполнительный Комитет, руководствуясь решением Президиума ВЦИК РСФСР от 1/XI - 1934 г. за № 132 постановляет организовать в г. Куйбышеве Краевое Отделение Общества Охраны Природы, действующее на основании Устава, утвержденного Президиумом ВЦИК РСФСР» [26, л. 56]. Однако это Постановление так и осталось невыполненным в связи с отсутствием средств на работу по охране природы, а также специалистов в данной области. Решение данного вопроса было отложено на неопределенный срок [26, л. 68]. Областное отделение ВООП появилось в Куйбышевской области только в 1957 г. А до этого времени, в течение двадцати одного года, ни краеведческая, ни природоохранная работа в области практически не велась.

После ареста В.П. Арапова и других местных краеведов в 1937 г., краеведческое движение в Куйбышевской области надолго прекратило свое существование. Данная тенденция была характерна для всей страны, так как 1937 год стал роковым для всего советского краеведения. В этом году Совнарком РСФСР принял постановление «О реорганизации краеведческой работы в центре и на местах», которое признало нецелесообразным «дальнейшее существо- вание Центрального и местных бюро краеведения» и предписало Наркомпросу их ликвидировать, так как для краеведческой работы нет никакой необходимости создавать специальные организации. Вся деятельность по краеведению передавалась в школы, вузы, музеи и дома культуры, а руководство ею и контроль возлагались на Наркомпрос и органы народного образования на местах [27]. После принятия этого постановления, краеведческое движение в СССР фактически перестало существовать. В конце 1940-х гг. Институт краеведения и музейной работы, изучив краеведческие организации страны, сделал вывод о том, что «при данном состоянии краеведения не может быть и речи о краеведческом движении, тем более о массовости советского краеведческого движения» [28, с. 190-201].

Тем не менее, за время своей работы в 1920-1930$\mathrm{x}$ гг. самарское краеведческое движение оставило уникальное научное наследие, значение которого сложно переоценить. Не имея достаточно сил и средств, работая безвозмездно, «на общественных началах», ученые и краеведы-любители сумели организовать всестороннее комплексное изучение Самарского края, в том числе его природы, и стать активными сторонниками и участниками российского природоохранного движения. В процессе исследования был сделан вывод о том, что общественное движение за охрану природы в 1920-1930-х гг. в Среднем Поволжье фактически существовало как отрасль краеведческого движения, имевшего разветвленную сеть первичных ячеек, сельских, городских и окружных обществ на местах. А достижения и традиции самарских ученых, которые появились в годы расцвета советского краеведения, несомненно, имеют большую ценность и в наши дни, являясь образцом для современных научных работников и краеведовлюбителей.

\section{СПИСОК ЛИТЕРАТУРЫ:}

1. Храмков Л.В. Введение в самарское краеведение. Самара: Изд-во ООО «Научно-технический центр», 2003. $350 \mathrm{c}$.

2. Центральный государственный архив Самарской области (далее - ЦГАСО). Ф. Р-558. Оп. 1. Д. 15.

3. ЦГАСО. Ф. Р-558. Оп. 1. Д. 16.

4. ЦГАСО. Ф. Р-558. Оп. 1. Д. 49.

5. ЦГАСО. Ф. Р-558. Оп. 1. Д. 74.

6. ЦГАСО. Ф. Р-558. Оп. 1. Д. 201.

7. ЦГАСО. Ф. Р-558. Оп. 1. Д. 75.

8. Гольмстен В.В. Общество археологии, истории, этнографии и естествознания при Самарском государственном университете (История и деятельность) // Бюллетень Общества археологии, истории, этнографии и естествознания. 1925. № 1. С. 3-9.

9. ЦГАСО. Ф. Р-558. Оп. 1. Д. 82.

10. ЦГАСО. Ф. Р-558. ОП. 1. Д. 219.

11. ЦГАСО. Ф. Р-558. Оп. 1. Д. 183.

12. ЦГАСО. Ф. Р-828. Оп. 3. Д. 158.

13. ЦГАСО. Ф. Р-779. Оп. 2. Д. 928.

14. ЦГАСО. Ф. Р-558. Оп 1. Д. 176.

15. ЦГАСО. Ф. Р-2558. Оп. 2. Д. 330.

16. ЦГАСО. Ф. Р-20. Оп. 1. Д. 17.

17. ЦГАСО. Ф. Р-558. Оп. 1. Д. 161.

18. ЦГАСО. Ф. Р-4377. Оп. 1. Д. 1.

19. ЦГАСО. Ф. Р-4377. Оп. 1. Д. 3. 
20. ЦГАСО. Ф. Р-828. ОП. 3. Д. 174

21. ЦГАСО. Ф. Р-558. Оп. 1. Д. 208.

22. ЦГАСО. Ф. Р-4377. Оп. 1. Д. 6.

23. ЦГАСО. Ф. Р-558. Оп. 1. Д. 206.

24. Гусева Л.В., Крайнова Т.В. «Мы не можем примириться...» (судьба последнего председателя Самарского общества археологии, истории, этнографии и естествознания В.П. Арапова) // Краеведческие записки. Вып. VIII, посвященный 110-летию музея. Самара: Самарский областной историкокраеведческий музей им. П.В. Алабина, 1996. С. 8998.

\section{SAMARA REGIONAL MOVEMENT 1920-1930 AND HIS CONTRIBUTION TO THE STUDY AND CONSERVATION OF THE MIDDLE VOLGA REGION}

(C) 2017

Makeeva Ekaterina Dmitrievna, candidate of historical sciences, associate professor of Physics, Mathematics and Methods of Teaching Department Samara State University of Social Sciences and Education (Samara, Russian Federation)

Abstract. Studying Russian environmental history is one of the urgent tasks of modern science as it allows you to use useful historical experience in conditions of aggravation of relations between society and nature. Nature protection in Russia has always been closely associated with the study of his homeland and his native land, being one of the most important areas of both academic and Amateur Ethnography. This article describes a contribution to the study and conservation of the Middle Volga Samara local history movement in the 1920s-1930s, including one of the most important scientific societies of the time - Samara society of archeology, history, Ethnography and natural Sciences and his successor. In its composition in the «Golden age studies» (1920s) worked the most famous scientists of the Samara, leaving a unique scientific legacy. Their work laid the foundations of modern science history, nature conservation and public movements for the protection of nature in the Samara region. Sources for the preparation of this article was mainly the Central state archive of the Samara region. A significant number of archival documents for the first time introduced into scientific circulation, which is the scientific novelty of the research.

Keywords: regional movement; local history; nature conservation; environmental protection; Samara society of archeology; history; Ethnography and natural Sciences; Samara scientific local lore society.

УДК 94(470.66) 50

Статья поступила в редакцию 28.02.2017

\section{К ВОПРОСУ ОБ ИСТОРИОГРАФИИ КАВКАЗСКОЙ ВОЙНЫ}

(C) 2017

Товсултанов Рустам Алхазурович, кандидат исторических наук, доцент кафедры новой и новейшей истории

Чеченский государственный университет (г. Грозный, Российская Федераиия)

Галимова Лилия Надиповна, доктор исторических наук,

профессор кафедры гуманитарных и социальных дисциплин

Ульяновский институт гражданской авиаџии имени главного маршала авиащии Б.П. Бугаева

(2. Ульяновск, Российская Федерация)

Оздамирова Элиза Мусатовна, старший преподаватель кафедры новой и новейшей истории Чеченский государственный университет (г. Грозный, Российская Федераџия)

\footnotetext{
Аннотация. Настоящая статья посвящена характеристике существующей многочисленной научной литературы имеющая значимые сведения истории Кавказской войны, на основе которой сделана попытка преодолеть историографический тупик в оценке и анализе этой противоречивой эпохи в истории взаимоотношений России и народов Северного Кавказа. Как известно в историографии Кавказской войны существуют многочисленные спорные моменты и разногласия. Наиболее ценный фактический материал по истории представляют работы современников. В данной статье в первую очередь проводится историографический анализ существующих точек зрения по данному вопросу. В работе дан подробный анализ состояния историографического освоения поставленной проблемы. Так как историография Кавказской войны является предметом острых дискуссий, и нередко толкуются крайне тенденциозно в исторической литературе, автор работы постарался объективно, основываясь на широком историографическом материале, внести свой вклад в объективное изучение истории Кавказской войны. Огромный вклад в изучение истории Кавказской войны внесла Всесоюзная научная конференция, которая открыла новый этап в изучении истории исследуемого события.

Фактический материал, системный его анализ позволяет обозначить характер, движущие силы и сущность Кавказской войны, также определить причины, вызвавшие эту войну, проанализировать причины зарождения идеологии мюридизма на Кавказе и детально изучить российско-северокавказские взаимоотношения.
} 